\title{
Coseismic effects of the 2016 Amatrice seismic sequence: first geological results
}

\author{
EMERGEO W.G.: PuCCI S. *, De MARTINI P.M. *, CiVICO R. *, NAPPi R. *, RicCi T.

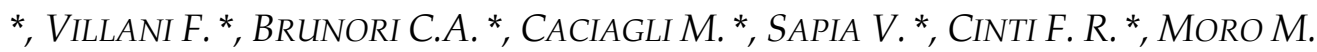 \\ *, Di NaCCIO D. *, Gori S. *, FALCUCCI E. *, VAllone R. *, MaZZarini F. *, \\ Tarquini $S .{ }^{*}$, Del Carlo P. ${ }^{*}$, Kastelic $V .{ }^{*}$, CARAFa M. *, De Ritis R. *, \\ Gaudiosi G. *, NAve R. *, Alessio G. *, Burrato P. *, SMedile A. *, Alfonsi L. *, \\ VAnNoli P. * Pignone M. * Pinzi S. *, Fracassi U. *, PizZimenti L. *, Mariucci \\ M.T. *, PAgliuca N. * Sciarra A. *, Carluccio R. *, Nicolosi I. *, Chiappini M. \\ *, D’Ajello Caracciolo F. *, Pezzo G. * , PAtera A. *, Azzaro R. *, Pantosti \\ D. ${ }^{*}$, MONTONE $P .{ }^{*}$, SAROLI M. ${ }^{\circ}{ }^{*}$, LO SARDO L. ${ }^{\circ}{ }^{*}$, LANCIA M. ${ }^{\circ}$, \\ *Istituto Nazionale di Geofisica e Vulcanologia \\ ${ }^{\circ}$ University of Cassino and southern Lazio
}

stefano.pucci@ingv.it

\begin{abstract}
Since the beginning of the ongoing Amatrice seismic sequence on August 24, 2016, initiated by a Mw 6.0 normal faulting earthquake, the EMERGEO Working Group (an INGV team devoted to earthquake aftermath geological survey) investigated coseismic effects on the natural environment. Up to now, we surveyed about $750 \mathrm{~km} 2$ and collected more than 3200 geological observations including differently oriented tectonic fractures together with intermediate- to small- sized landslides. The most impressive coseismic evidence was found along the known active Mt. Vettore fault system, where surface ruptures with clear vertical/horizontal offset were observed for more than $5 \mathrm{~km}$, while unclear and discontinuous coseismic features were recorded along the Laga Mts. Fault systems.
\end{abstract}

\section{INTRODUCTION}

August 24, 2016, at 1:36 UTC an Mw 6.0 earthquake hit a large portion of the central Apennines fold and thrust belt, between the towns of Norcia and Amatrice, central Italy (Fig.1). The event nucleated at a depth of $8.2 \mathrm{~km}$, with epicenter close to the village of Accumoli (Fig. 1) [AMA_LOC
The mainshocks caused heavy damage in a wide area between the towns of Norcia and Amatrice and resulted in 298 fatalities, thousands of injured and over 3000 displaced people.

Focal mechanisms of the two main events show NW-SE striking normal faulting (Fig. 1). The seismic sequence was confined within the 
upper $10-12 \mathrm{~km}$ of the crust and the volume affected by the aftershocks extends for about 50 and $15 \mathrm{~km}$ in the NW-SE and NE-SW directions, respectively.

This area of the central Apennines is characterized by a Quaternary extensional regime overprinting NE-verging thrust-sheets (i.e. Vai and Martini, 2001 and references therein), mostly made of Meso-Cenozoic carbonate rocks and Miocene flysch deposits. The resulting dense array of NW-SE and
NNW-SSE striking, mainly SW- dipping, up to $30 \mathrm{~km}$-long active normal fault systems (Galli et al., 2008 and references therein; Fig. 1) accommodate the present-day $2-4 \mathrm{~mm} / \mathrm{yr}$ regional NE-SW extension (Galvani et al., 2013, and references therein).

In this paper we present the dataset of coseismic effects on the natural environment collected by the Emergeo Working Group together with a preliminary discussion.

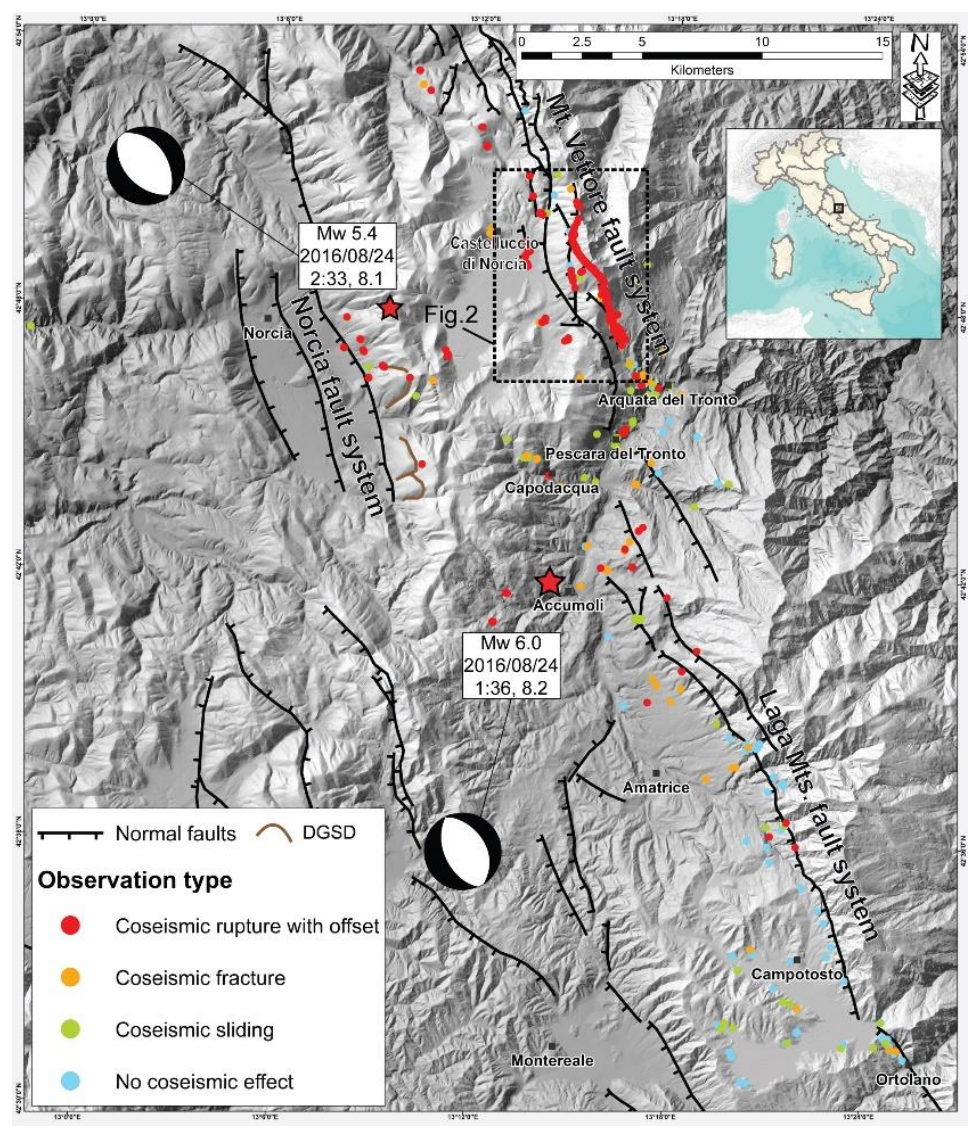

Figure 1. Location of the measurements and observations collected in the field. Normal faults are compiled from geological maps [Centamore et al., 1992; Pierantoni et al., 2013]. Hillshade from TINITALY 10m-DEM [Tarquini et al., 2012]. The 24 August 2016 mainshock and largest aftershock are reported with red stars. TDMT focal mechanisms available at http://cnt.rm.ingv.it/event/7073641 and http://cnt.rm.ingv.it/event/7076161. DGSD (deep-seated gravitational slope deformations) with evidence of coseismic fracturing are shown. 


\section{METHODS}

Field surveying of the coseismic effects by EMERGEO was mainly performed by using smartphones equipped with a range of software that use the phone's GPS, compass and orientation sensors. We used the Rocklogger application (rockgecko.com) to measure and store the data of the coseismic effects (type of observation, strike, vertical dislocation, fracture opening, etc.). GPS track loggers were used for monitoring and subsequent planning the survey coverage. Low-altitude, easy deployable, aerial platforms (helikite and unmanned aerial vehicles UAVs), together with a helicopter flight, have been used to support the post-earthquake documentation of surface ruptures. A webbased data sourcing was utilized to gather information on coseismic geological effects from local people. The collected data have been stored in a georeferenced-database (for details see EMERGEO Working Group, 2012).

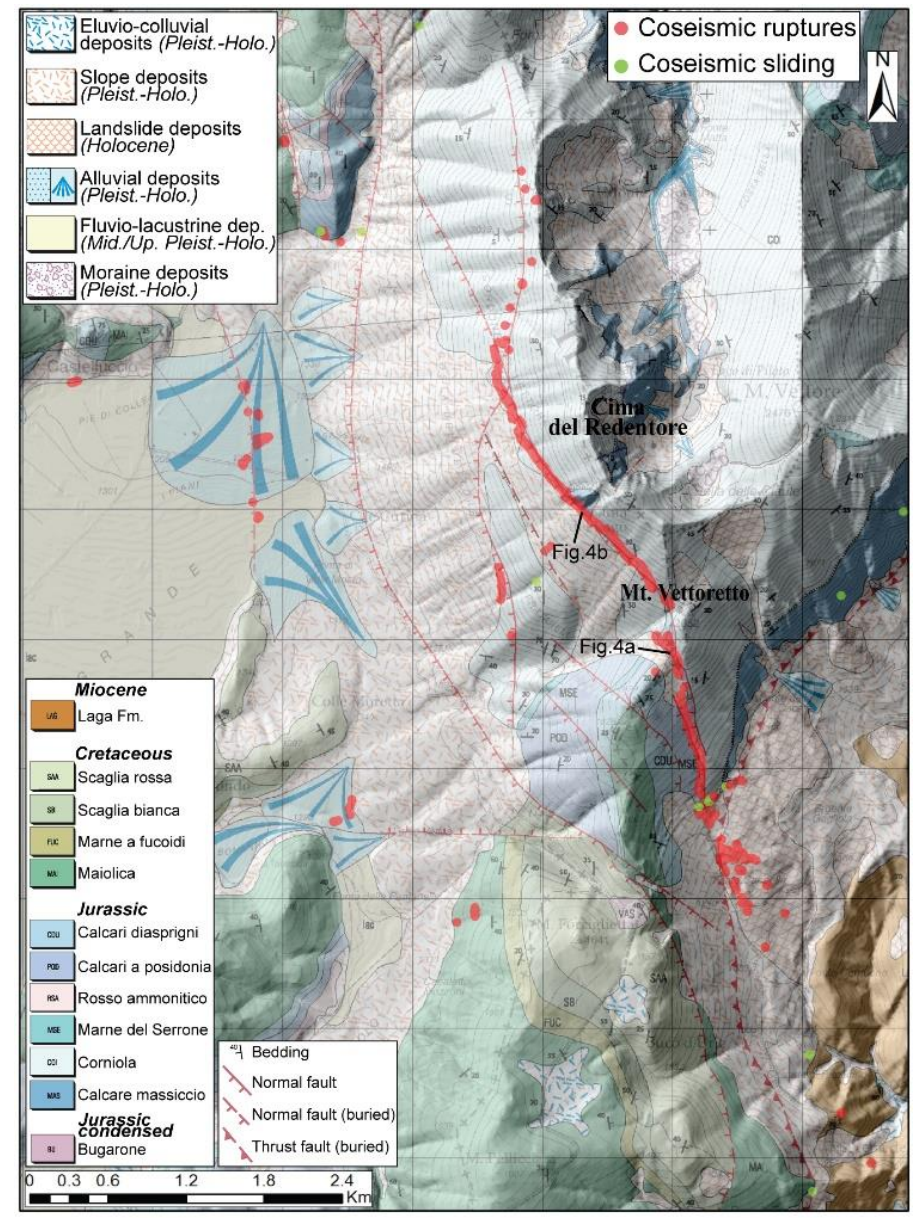

Figure 2. Map of the coseismic geological effects of the Mt. Vettore area. Geological map from Pierantoni et al. [2013]. Hillshade from TINITALY 10m-DEM [Tarquini et al., 2012]. 


\section{RESULTS}

We surveyed an area of about $750 \mathrm{~km}^{2}$, recording more than 3200 measurements and observations. Among them, we collected: 230 coseismic fracture $(<1 \mathrm{~cm}$ displacements) and 2600 coseismic rupture ( $>1 \mathrm{~cm}$ displacements) measurements; evidence for 160 medium- to small-sized coseismic landslides, 28 coseismic features related to the shaking (e.g. clast extrusions, soil remobilization, etc.), and 130 locations where we documented the lack of coseismic effects. In addition, a fracturing pattern is hypothesised in the trench sector and along the upper limit of 3 DGSD (deepseated gravitational slope deformations) between the villages of Castelluccio and Norcia as due to coseismic-induced acceleration (Fig. 1).

The inspection of the Laga Mts. Fault System provided only few sparse observations of discontinuous (maximum 300 m-long) equivocal ruptures with small displacements (maximum $5 \mathrm{~cm}$ ), mostly concentrated along its northern sector. A few ruptures exhibit a trend parallel to the mapped fault, whereas most of them do not have a systematic pattern. In contrast, in the central-southern portion of this fault, no clear coseismic fracturing or rupturing was observed, but several coseismic landslides (rotational and rock falls) occurred, possibly due to the shear strength of the outcropping pelitic formations. Some of them are pre-existing landslides re-activated, partly known and mapped after the 2009 L'Aquila earthquake (Miccadei et al., 2013).

Conversely, to the north, along the Mt. Vettore Fault System, a continuous alignment of newly formed coseismic ruptures was mapped for more than $5.2 \mathrm{~km}$. The coseismic ruptures follow the Cima del Redentore and Mt. Vettoretto SW-dipping and $\mathrm{N} 155^{\circ}$-striking normal faults (Fig. 2). The coseismic ruptures occur along a cumulative fault scarp made by bedrock at the footwall (mostly Corniola Fm.) and by highly fractured bedrock as well as unconsolidated deposits (generally cryoclastic debris) at the hanging wall. A few additional coseismic ruptures parallel continuously a southern fault splay for more than $400 \mathrm{~m}$ along the SW-flank of the Mt. Vettore, and another discontinuous set occurs at the slope foot, resulting in an alignment $1.2 \mathrm{~km}$ long (Fig. 2). In detail the $5.2 \mathrm{~km}$-long rupture consists of 5$6 \mathrm{~m}$ long segments, each up to 5-6 m-long, mostly displaying a right-stepping en-echelon arrangement (Fig. 3, 4a). The deformation zone width is generally confined on a single ground crack, rarely exceeding $5 \mathrm{~m}$ where maximum three parallel ground cracks and ruptures were found. The orientation of the different elements composing the coseismic rupture is: 1) $\mathrm{N} 125^{\circ}-140^{\circ}$ for the coseismic ruptures (with offset) affecting unconsolidated deposits; 2) $\mathrm{N} 105^{\circ}-140^{\circ}$ for coseismic fractures (with no offset) affecting unconsolidated deposits; 3) $\mathrm{N} 130^{\circ}-175^{\circ}$ for coseismic ruptures occurring on the bedrock fault planes (coseismic free faces) (Fig. 3). Notably, the trend of the ruptures south of Mt. Vettoretto is oblique with respect to the slope, while northward, it becomes perpendicular to the slope of the southwestern Mt. Vettore flank (Fig. 3).

The coseismic rupture pattern is not influenced by the bedrock bedding attitude, while locally it re-utilizes joints. The rupture trace preserves its trend, even when cutting through debris cone apexes. 


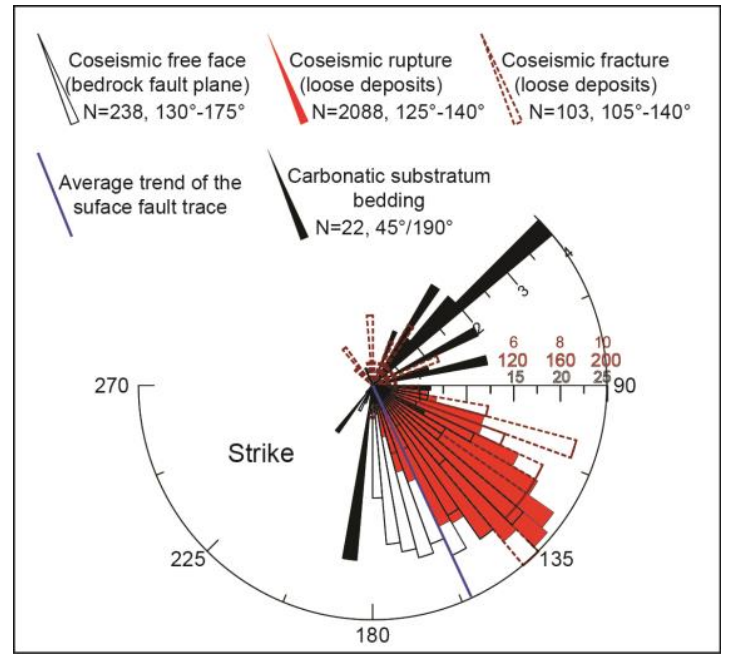

Figure 3. Geometrical pattern of the Mt. Vettore coseismic ruptures. The rose diagram shows different trends of the coseismic free face, rupture and fracture measurements with respect to the bedrock bedding and the average trend of the fault trace.

On bedrock fault planes, the newly formed free face looks like a fresh, light-coloured stripe of rejuvenated bedrock surface, with no lichens and soil shade (Fig. 4b). The coseismic ruptures always down-throw the SW side with vertical displacement being mostly below 16 $\mathrm{cm}$ and exceeding $35 \mathrm{~cm}$ in few locations of its northern portion (Fig. 5a). Moreover, the vertical displacement of the coseismic free faces is mostly between 16 and $20 \mathrm{~cm}$. The width of open cracks is mostly below $16 \mathrm{~cm}$

\section{DISCUSSION AND CONCLUSION}

Based on the characteristics and distribution of the coseismic effects related to the 24 August 2016 Amatrice earthquake, we identified two areas: the Laga Mts. Fault System, to the south and the Mt. Vettore Fault System to the north. Along the northern portion of the Laga Mts. Fault System few sparse evidences of with few outliers (up to $40 \mathrm{~cm}$ ) along its central portion for both coseismic ruptures and free faces (Fig. 5b). Notably, the almost $2 \mathrm{~km}$ long coseismic ruptures south of Mt. Vettoretto tend to revert the topography.

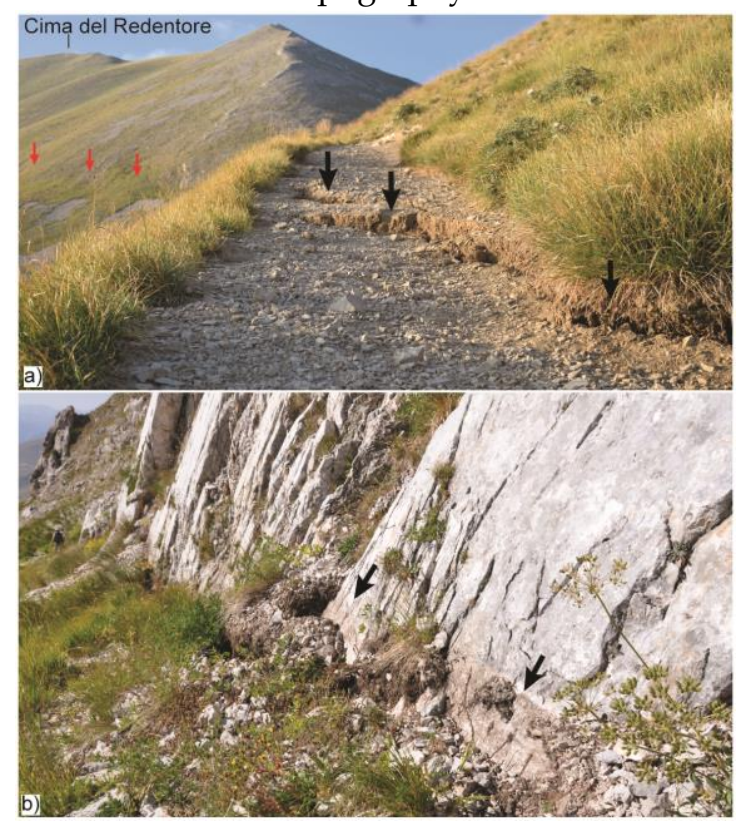

Figure 4. Photos of the Mt. Vettore coseismic ruptures. a) en-echelon coseismic ruptures (black arrows) affecting unconsolidated slope deposits and a trail, the red arrows mark the Mt. Vettore fault scarp; $b$ ) coseismic free face on bedrock fault plane (black arrows).

discontinuous coseismic ruptures with small displacements were surveyed, while in the central-southern portion of this fault, no significant fracturing at the surface was observed. In general, along the Laga Mts. Fault System there is no clear deformation as expression of the seismogenic fault plane motion occurred at depth. A possible explanation for this negative evidence is due to the thick sequence (ca. 1-2 km) of flysch and marls, which may accommodate the coseismic 
deformations without a purely brittle behavior.

Along the Mt. Vettore Fault System sector we documented a localized and continuous concentration of coseismic ruptures with offset. Main characteristics are: i) the considerable length of the continuous alignment (more than $5 \mathrm{~km}$ ); ii) the consistency of the structural pattern (often characterized by right en-echelon arrangement with kinematically coherent oblique transfer zones); iii) the downthrown side is systematically the SW one; iv) the structural pattern, the kinematics and the offset distribution is not influenced by topography and morphology (e.g. erosional scarp and debris cone crosscut, Figs. 3 and 5), v) the constant rupture characteristics over both bedrock and loose deposits.

All these features lead to infer that the observed displacement could be defined as primary surface faulting (i.e. propagation up to the surface of the seismogenic motion occurred at depth). However, shaking/gravity effects may have locally contributed to part of the observed displacement. shaking/gravity effects may have locally contributed to part of the observed displacement.

A number of authors (P. Burrato, M. Carafa, D. Di Naccio, U. Fracassi, V. Kastelic, R. Vallone and P. Vannoli) are doubtful in straightforwardly interpreting the surveyed brittle features as effects of primary surface faulting. Rather, they maintain that the geologic and morphologic conditions have favored the instability of jointed and faulted rocks and unconsolidated sediments under dynamic conditions. Therefore, the hypothesis of the observed fractures as secondary earthquake effects driven by blind faulting cannot be ruled out a priori.

We all agree on the fact that future detailed comparison with other datasets like seismicity relocations, satellite data (InSAR and GPS) and modeling inversions of different seismic parameters will help in better understanding and evaluating the gravitational component vs tectonic displacement. 

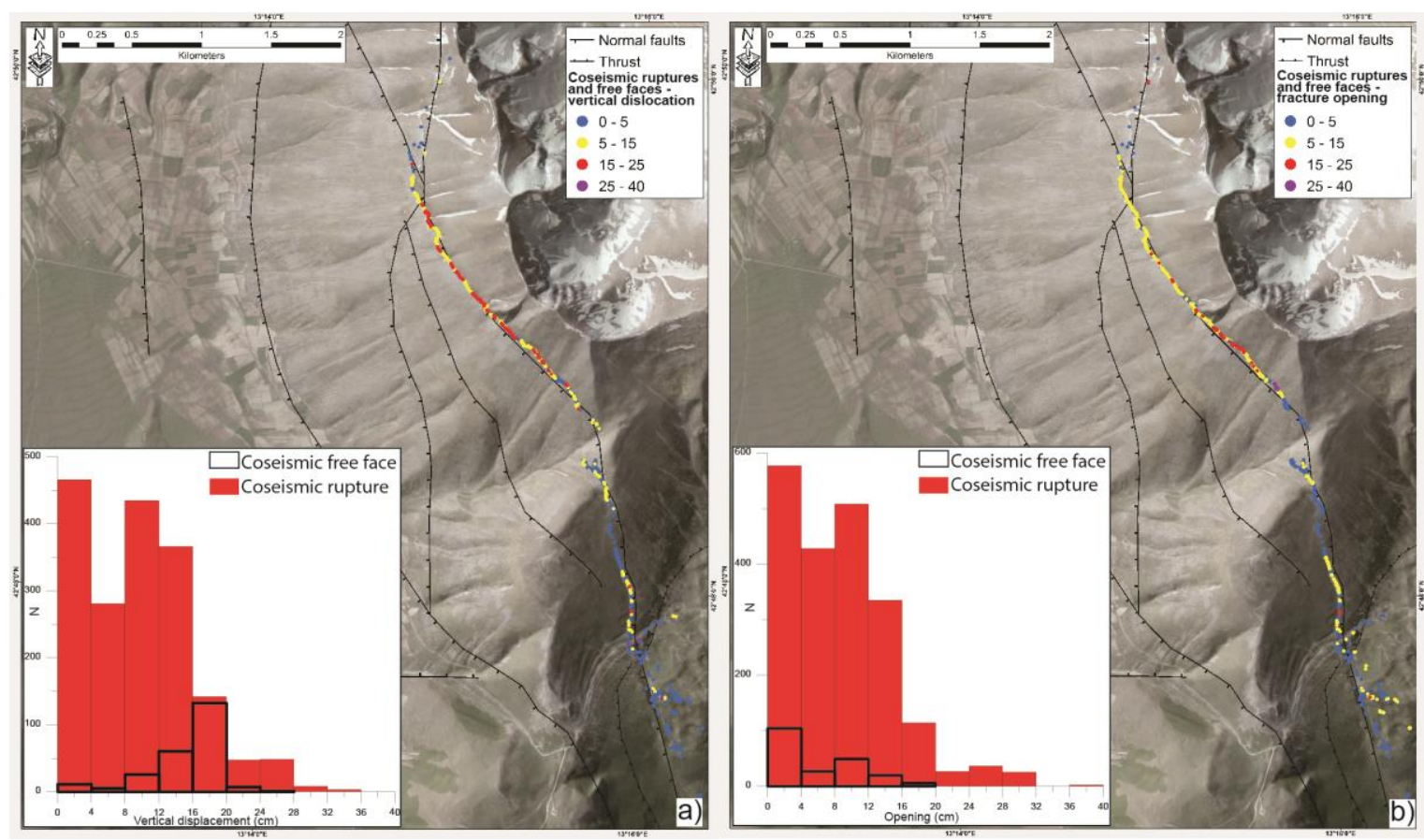

Figure 5. Variation in displacement along the strike of the Mt. Vettore coseismic ruptures. Distribution of a) vertical displacement and b) opening values. The inset shows the frequency of the displacements for ruptures in coincidence of loose deposits (coseismic rupture) and along preexisting bedrock fault planes (coseismic free face).

\section{REFERENCES}

AMA_LOC Working Group (2016). Amatrice 2016 main events re-location (v1.0 - 20160902 12.00). Istituto Nazionale di Geofisica e Vulcanologia. DOI 10.5281/zenodo.61371

Centamore, E., Adamoli, L., Berti, D., Bigi, G., Bigi, S., Casnedi, R., Cantalamessa, G., Fumanti, F., Morelli, C., Micarelli, A., Ridolfi, M., and Salvucci, R. (1992). Carta geologica dei bacini della Laga e del Cellino e dei rilievi carbonatici circostanti. In: Studi Geologici Camerti, Vol. Spec. Università degli Studi, Dipartimento di Scienze della Terra. SELCA, Firenze.

EMERGEO Working Group: Alessio, G., L. Alfonsi, C.A. Brunori, P. Burrato, G. Casula, F.R. Cinti, R. Civico, L. Colini, L. Cucci, P.M.
De Martini, E. Falcucci, F. Galadini, G. Gaudiosi, S. Gori, M.T. Mariucci, P. Montone, M. Moro, R. Nappi, A. Nardi, R. Nave, D. Pantosti, A. Patera, A. Pesci, M. Pignone, S. Pinzi, S. Pucci, P. Vannoli, A. Venuti and F. Villani (2012). Technologies and new approaches used by the INGV EMERGEO Working Group for real time data sourcing and processing during the Emilia Romagna (northern Italy) 2012 earthquake sequence, Annals of Geophysics, 55, 4, 2012; doi: 10.4401/ag-6117.

Galli, P., F. Galadini and D. Pantosti (2008). Twenty years of paleoseismology in Italy. Earth-Science Reviews, 88, 89-117.

Galvani, A., M. Anzidei, R. Devoti, A. Esposito, G. Pietrantonio, A.R. Pisani, F. Riguzzi and E. Serpelloni (2013). The 
interseismic velocity field of the central Apennines from a dense GPS network, Annals of Geophysics, 55, 5, doi: 10.4401/ag-5634

Miccadei, E., T. Piacentini, N. Sciarra and R. Di Michele (2013). Seismically induced landslides in Abruzzo (Central Italy): morphostructural control. In Landslide Science and Practice (pp. 315-320). Springer Berlin Heidelberg.

Pierantoni, P., G. Deiana and S. Galdenzi (2013). Stratigraphic and structural features of the Sibillini Mountains (Umbria-Marche Apennines, Italy). Italian Journal of Geosciences, 132(3): 497-520.
Tarquini, S., S. Vinci, M. Favalli, F. Doumaz, A. Fornaciai and L. Nannipieri (2012). Release of a 10-m-resolution DEM for the Italian territory: Comparison with global-coverage DEMs and anaglyph-mode exploration via the web. Computers \& geosciences, 38(1), 168-170.

Vai, G.B., and L.P. Martini (Ed.), (2001). Anatomy of an orogen: the Apennines and adjacent Mediterranean basins, Kluwer Academic Publishers, Dordrecht, The Netherlands, 633 p. 